\title{
研究者の年齢と能力
}

\author{
フェロー 金谷 健一
}

岡山大学名誉教授

\section{20 歳代ピーク説}

恩師の甘利俊一先生 (現在, 理化学研究所) は これまでいろいろな機会に研究者の年齢と能力 について話され, 先日の文化功労者顕彰祝賀会 でも述べられた。 甘利先生によれば, 昔から学 者の才能は 20 歳代がピークで, その後は衰える 一方といわれていて, 自分が 20 歳代のときはそ う思っていた。しかし 30 歳代になると 30 歳代 が, 40 歳代になると 40 歳代が, 50 歳代になる と 50 歳代が, と常にその時点がピークのように 思え, 今は現在の 70 歳代がピークのようだとい うことである.

しかし，自分自身のことを考えると，やはり 20 歳代がピークと考えるのが正しいと思われる. それでは 20 歳代に一番優れた業績を出したかと 問われると, 私の 20 歳代の学位研究 (内部構造 を持つ連続体の力学) は確かに外国論文誌や国 際会議で新人としては異例に評価され, 現在で も引用する論文が投稿されて私に査読依頼が来 たりしているが，私としてはそれほどの意義が あるとも思えない，全てを自分一人で成し遂げ， その後の研究者生活の基礎を築いたところに価 值があるとしても，学問的な意義は私が後に取 り組んだコンピュータビジョンの数理解析にあ ると考えている。 そして, その成果は 30 歳代, 40 歳代, 50 歳代を通して継続的に発展し, 最も 優れたものは私の定年退職直前の 2011 年, 2012 年に発表した理論解析と応用ではないかと考え ている，これは 20 歳代ピーク説に反するようで あるが, そうではない.

\section{2. 研究活動二計算機システム}

私は研究活動を計算機システムに例えるのが よいと考えている. 個人の能力は CPU性能に相 当し, これは 20 歳代がピークであろう. しかし, 計算機システム全体の性能は CPU 能力だけで はない. 30 歳代, 40 歳代になると OS, すなわ ちタスクの割当や効率化の能力が発達して, そ れが研究発展の基になった。 そして 40 歳代, 50 歳代になると外部記憶装置が発達して, 知識や ノウハウが蓄積され，研究成果がますます増え た. 50 歳代， 60 歳代になると今度はネットワー クが発達して，世界中の研究者との交流が増え て更に研究が進展した。

\section{3. 研究のネットワーク}

このネットワークについて具体的な例を述べ る. 1990 年代の初頭に私は「くりこみ法」と 命名した幾何学的な推定手法を考案して満足 していた．ところがオーストラリアの Wojciech Choninacki と Mike Brooks が当時私の所属して いた群馬大学の研究室を訪れ，私のくりこみ法 を発展させたFNS 法という手法を説明した。私 は非常にショックを受けたが，それを調べてい く中から，精度を理論的に解析する手法を見出 し、いろいろな発表を行った。すると 2008 年 に米国南メソジスト大学の Ph.D. 学生 Prasanna Rangarajana が, 私の解析手法を使うと従来の 方法より著しく精度が高い手法が得られるといっ てきた，驚いたが，調べると確かにそうである． そこで彼を岡山大学に招聘し, その手法を「超 精度最小二乗法」と命名して連名でいろいろな 
発表を行った，すると 2010 年に今度は米国アラ バマ大学数学科の Ph.D. 学生の Ali Alsharadqah が，超精度最小二乗法を工夫すると更に精度が 向上するといってきた，驚いたが，調べると確か にそうある。そこで彼を岡山大学に招聘し，そ の手法を「超精度くりこみ法」と命名して連名 でいろいろな発表を行った。

2011 年にはトルコのイスタンブール工科大学 の測地学者 Orhan Akyilmaz が, 私が 1990 年代 に書いた回転の最適推定の論文の式の一部に誤 りがあると指摘した，それが契機でトルコに行っ た機会に Akyilmaz 博士と会って GPS による地 盤計測のことを学んだ。これが基になって地盤 の相似変換の最適推定の発表を行った。 すると, 2012 年にその論文を見た（株）朋栄の松永力氏 から，それを私が 1990 年代に発表した「拡張 FNS 法」と組み合わせると, 回転や相似変換の みならず，任意の変換に拡張できるという指摘 があった，拡張 FNS 法は Choninacki らの FNS 法の拡張である. 彼らはそれを制約のある問題 に発展させた「制約 FNS 法」という手法を発表 したが，それに問題があることを共同研究を行っ ていた豊橋技術科学大学の菅谷保之氏が指摘し, それを菅谷氏と共同で改良したのが拡張 FNS 法 である，私は松永氏の指摘に驚いたが，調べる と確かにそうある。 そこで松永氏と連名で幾つ かの発表を行った。

\section{4. 研究に年齢はない}

このように，これまで自分で研究を進めてい ると, これが最終到達点だ，これ以上の進展は ないと思ったことが何度もあった。しかし，そ のたびに他人から更に発展ができることを指摘 され，しかもその源泉が私自身の中にあって自 分では気付かなかったということを何度も経験 した。

このような経験から私からのメッセージは, 年 をとってもいくらでも研究成果が出せるという
ことである，個人としての能力は確かに衰える が，それを補うのが人とのネットワークである。 良い研究を発表すれば必ず世界中の人の目に触 れ，関心を持つ人がいる，そういう人たちと交 流すれば研究がますます進展する。

\section{5. 日本語で論文を書かない}

私が特に強調したいのは日本語で論文を書か ない，論文は必ず英語で書く，ということであ る。私は自分のカメラ校正の研究に関連して, 2000 年代に日本人研究者が電子情報通信学会論 文誌に和文で発表したのと全く同じ手法を後に 外国人が IEEE PAMIに発表しているのを見た. もちろん和文論文は引用されていない，私自身 も同じような経験をした，私が 1990 年代に電子 情報通信学会論文誌に発表したカメラ校正の原 理と同様で，しかもより原始的な手法を 2000 年 代にフランスの Faugeras や米国の Nayer らが発 表し, 現在でも日本人研究者の間でさえ, 彼ら がその原理の提唱者として引用され，私の 1990 年代の和文論文を引用する人はいない．

\section{6. コミュニケーション能力}

研究が国際化した今日では論文は英語で書か なければならないが，人に関心を持ってもらう ためには，自分の研究を人に分かりやすく説明 することが重要である，そのためには，分かり やすい英文を書くだけでなく，口頭発表やディ スカッションでも説得力のある英語で説明でき る必要がある，若い人たちがこのようなコミュ ニケーション能力によってますます研究を発展 させることを期待している. 